\title{
Acrylamide does not induce tumorigenesis or major defects in mice in vivo
}

\author{
Ling Jin*, Vanessa Chico-Galdo*, Claude Massart, Christine Gervy ${ }^{1}$, Viviane De Maertelaere, \\ Marvin Friedman ${ }^{2}$ and Jacqueline Van Sande \\ Faculté de Médecine, Institute of Interdisciplinary Research (IRIBHM), Universtité Libre de Bruxelles, Campus Erasme, Route de Lennik 808, \\ B 1070 Brussels, Belgium \\ ${ }^{1}$ Clinical Biochemistry Department, Hôpital Erasme, B 1070 Brussels, Belgium \\ ${ }^{2}$ University of Medicine and Dentistry of New Jersey, Oviedo, Newark, New Jersey, USA \\ (Correspondence should be addressed to V Chico-Galdo; Email: vchicoga@ulb.ac.be) \\ *(L Jin and $\mathrm{V}$ Chico-Galdo contributed equally to this work)
}

\begin{abstract}
Chronic administration of acrylamide has been shown to induce thyroid tumors in rat. In vitro acrylamide also causes DNA damage, as demonstrated by the comet assay, in various types of cells including human thyroid cells and lymphocytes, as well as rat thyroid cell lines. In this work, mice were administered acrylamide in their drinking water in doses comparable with those used in rats, i.e., around $3-4 \mathrm{mg} / \mathrm{kg}$ per day for mice treated 2, 6, and 8 months. Some of the mice were also treated with thyroxine $\left(T_{4}\right)$ to depress the activity of the thyroid. Others were treated with methimazole that inhibits thyroid hormone synthesis and consequently secretion and thus induces TSH secretion and thyroid activation. These moderate treatments were shown to have
\end{abstract}

their known effect on the thyroid (e.g. thyroid hormone and thyrotropin serum levels, thyroid gland morphology...). Besides, $T_{4}$ induced an important polydipsia and degenerative hypertrophy of adrenal medulla. Acrylamide exerted various discrete effects and at high doses caused peripheral neuropathy, as demonstrated by hind-leg paralysis. However, it did not induce thyroid tumorigenesis. These results show that the thyroid tumorigenic effects of acrylamide are not observed in another rodent species, the mouse, and suggest the necessity of an epidemiological study in human to conclude on a public health policy.

Journal of Endocrinology (2008) 198, 301-307

\section{Introduction}

Acrylamide is a chemical used for various scientific and industrial processes. It is also an alimentary byproduct of high carbohydrate- and asparagine-containing food cooked at high temperature, resulting from the reaction of reducing sugars with amino acids. The most important metabolite of acrylamide is glycidamide. Both chemicals conjugate to glutathione. Acrylamide ingestion has been shown in animals to be responsible for various toxic effects such as neuropathies, effects on reproduction, thyroid and mammary tumorigenesis (Tanii \& Hashimoto 1983, Johnson et al. 1986, Friedman et al. 1995, Tyl et al. 2000). The literature on the subject has been recently extensively reviewed (Shipp et al. 2006). In rats, chronic administration of acrylamide ( 2 and $3 \mathrm{mg} / \mathrm{kg}$ per day) has been shown to induce after 24 months tumors of the thyroid, mammary gland, and tunica vaginalis mesotheliomas (TVMs), the most frequent (23\%) overall being the thyroid ones (Friedman et al. 1995). However, if sexes are compared separately, TVMs and mammary gland tumors were more frequent. The thyroid tumors were classified as follicular adenomas and carcinomas, the incidence of only the former being statistically significant. Chronic administration of acrylamide for 6-8 weeks also induced an increase in BrdU incorporation in rat thyroids (Lafferty et al. 2004). In vitro, we have shown that acrylamide at concentrations from $100 \mu \mathrm{M}$ to $3 \mathrm{mM}$ induced DNA damage, as demonstrated by the comet assay, not only in $\mathrm{PC} \mathrm{Cl} 3$ rat thyroid cell lines but also in human and dog thyroid cells in primary cultures. These effects were smaller than those induced by $\mathrm{H}_{2} \mathrm{O}_{2}$ or etoposide (a topoisomerase II inhibitor inducing DNA double-strand breaks) but they were consistent. Acrylamide did not affect iodination and $\mathrm{H}_{2} \mathrm{O}$ generation in human, $\mathrm{dog}$, and PC Cl3 cells, nor cell proliferation in FRTL5 rat thyroid cell line. Acrylamide also causes positive comet assays in human lymphocytes in vitro (Blasiak et al. 2004). DNA damage when incompletely or improperly repaired gives rise to mutations, and mutagenesis is a recognized cause of carcinogenesis (Foth et al. 2005). Therefore, the in vitro studies provided a potential mechanistic explanation for the in vivo carcinogenic action of acrylamide. However, as the chronic in vivo studies that were carried out only in rats, and as investigation of workers professionally exposed to higher than normal doses of 
acrylamide or individuals with higher consumption, do not reveal any obvious diseases besides some evidence of neuropathy (Collins et al. 1989, Marsh et al. 1999, Mucci et al. 2003), we undertook a new chronic in vivo study on another animal species: the mouse. If acrylamide had effects in this species, we could investigate mechanisms in depth using our transgenic models. We modulated the activation of the thyroid positively by blocking thyroid hormone synthesis with methimazole (MMI) and negatively by administering thyroxine $\left(\mathrm{T}_{4}\right)$, expecting acrylamide-induced tumorigenesis to be enhanced by stimulation and depressed in quiescent tissue. The results show that whatever the functional state of the thyroid, acrylamide at the dosage used does not induce thyroid tumorigenesis in the strain of mice studied.

\section{Materials and Methods}

\section{Animals}

The experiments were performed on CD1 strain female mice (8 weeks old) from Charles River (L'arbresle, France). In total, 150 female mice were used for each experiment and were identified by finger tattoo and cage numbers. All the mice were fed a normal iodine diet and maintained in the animal facility under $12 \mathrm{~h}$ light: $12 \mathrm{~h}$ darkness cycle in accordance with the principles of laboratory animal care. These mice were randomly divided into two big groups: 75 mice were not exposed to acrylamide and 75 mice got acrylamide exposure. Each big group was then divided into three subgroups: group 1, 20 mice getting only $\mathrm{H}_{2}$; group 2, 25 mice exposed to $\mathrm{T}_{4}$; group 3, 30 mice treated with MMI; group 4, 20 mice getting acrylamide, group 5, 25 mice exposed to acrylamide and $\mathrm{T}_{4}$; and group 6, 30 mice treated with acrylamide and MMI. Acrylamide (GibcoBRL), $\mathrm{T}_{4}$ (Sigma), and MMI (Sigma) were dissolved in the drinking water.

Two different studies were performed. We performed a short term, 2-month study, made up of 150 mice divided into six groups, and a longer study, comprising the same number of mice but treated for 6 or 8 months.

In the 2-month study, the concentration of $\mathrm{T}_{4}$ in water was $2 \mathrm{mg} / \mathrm{l}$, MMI was $100 \mathrm{mg} / \mathrm{l}$ during the length of the treatment, and acrylamide was $10 \mathrm{mg} / \mathrm{l}$ for the first 4 weeks then adjusted to $15 \mathrm{mg} / \mathrm{l}$ to achieve $3 \mathrm{mg} / \mathrm{kg}$ per day.

In the long-term study, the concentration of $\mathrm{T}_{4}$ was $2 \mathrm{mg} / 1$ at the start but had to be decreased to $0.4 \mathrm{mg} / \mathrm{l}$ after 2 months because of the onset of mortality in these groups. The concentration of MMI was $200 \mathrm{mg} / \mathrm{ml}$ and that of acrylamide was adjusted around $25 \mathrm{mg} / \mathrm{l}$ according to the water intake to achieve $3 \mathrm{mg} / \mathrm{kg}$ per day. For the last 6 weeks, we boosted the acrylamide concentration to $82.5 \mathrm{mg} / \mathrm{l}$ to achieve $10 \mathrm{mg} / \mathrm{kg}$ per day. Due to the increase in water intake in the $\mathrm{T}_{4}$-treated animals (Fig. 2), the concentration of acrylamide in the $\mathrm{T}_{4}+$ acrylamide group was adjusted. In the MMI+acrylamide group, acrylamide was 28.4 and $93.7 \mathrm{mg} / \mathrm{l}$ for the last 2 months.
The mice were weighed weekly and their water was changed twice a week. The amount of water drunk by each group per week was measured all through the experiment, allowing us to evaluate and adjust the intake of chemicals.

In our longer term study, the animals treated with $\mathrm{T}_{4}$, with or without acrylamide became ill and had to be killed after the 6-month treatment period. On the other hand, in view of the absence of obvious effects of acrylamide at the dosage used, the treatment with acrylamide for the other mice was upgraded for another 2 months to $10 \mathrm{mg} / \mathrm{kg}$ per day.

Plasma free tri-iodothyronine $\left(\mathrm{FT}_{3}\right)$ and $\mathrm{FT}_{4}$ measurements were carried out by RIA (Roche). The signal of the reaction is chemiluminescence read on Modular Analytics E170 Roche. For $\mathrm{FT}_{3}$, the coefficient of variation (CV) is less than $3 \cdot 4 \%$ for values between 2 and $13 \mathrm{pg} / \mathrm{ml}$ and for $\mathrm{FT}_{4}$ the $\mathrm{CV}$ is less than $3.5 \%$ for values between 0.7 and $4 \mathrm{ng} / \mathrm{dl}$.

Thyrotropin (TSH) was evaluated by bioassay using a line of Chinese hamster ovary cells (CHO-K1) stably transfected with a human TSH receptor cDNA, as previously described (Perret et al. 1990). Briefly, 50000 cells were seeded in individual test tubes and incubated for $24 \mathrm{~h}$ in $100 \mu \mathrm{l} \mathrm{Ham}$ 's F12 cell culture medium supplemented with $10 \%$ fetal calf serum, $100 \mathrm{IU} / \mathrm{ml}$ penicillin, $100 \mu \mathrm{g} / \mathrm{ml}$ streptomycin, $1 \mathrm{mM}$ sodium pyruvate, and $2.5 \mu \mathrm{g} / \mathrm{ml}$ Fungizone. Cells were washed with $500 \mu \mathrm{l}$ Krebs-Ringer-HEPES buffer ( $\mathrm{pH} 7 \cdot 4$ ) supplemented with $8 \mathrm{mM}$ glucose and $0.5 \mathrm{~g} / 1 \mathrm{BSA}$ and then pre-incubated for $30 \mathrm{~min}$ in $200 \mu \mathrm{l}$ of the same medium. The medium was removed and $200 \mu \mathrm{l}$ fresh medium containing $20 \mu \mathrm{l}$ serum for TSH measurement and $25 \mu \mathrm{M}$ Rolipram, a cAMP phosphodiesterase inhibitor, were added. After 1-h incubation, the medium was discarded and replaced with $1 \mathrm{ml}$ $0 \cdot 1 \mathrm{M} \mathrm{HCl}$. cAMP was measured in the dried cell extract by RIA according to the method of Brooker et al. (1979). The values obtained with $\mathrm{CHO}-\mathrm{K} 1$ cells devoid of TSH receptor were considered as blank. This assay has been validated as a functional bioassay of serum TSH (Pohlenz et al. 1999). All biochemical results are expressed as means \pm s.D.

\section{Histology}

Pituitary, thyroid, lung, liver, spleen, adrenal and kidney, urinary bladder, and reproductive tracts (including ovaries, uterine horns, cervix, and vagina) were macroscopically examined for the development of neoplasm. Pituitary, thyroid, and adrenal glands, reproductive tracts, and one lung that had one neoplasm were fixed in $4 \%$ paraformaldehyde and embedded in paraffin. The pituitary, thyroid, and adrenal glands were weighed before fixation.

Five micrometer serial sections were cut and laid on SuperFrost Plus glass slides (Menzel-Glaser, Brauschweig, Germany). Three serial sections (5 $\mu \mathrm{m}$ thickness) were deparaffinated in toluene and rehydrated using an ethanol gradient. The first serial sections were stained with hematoxylin-eosin (H\&E). The second and third serial sections were used for the detection of thyroid-specific proteins thyroglobulin $(\mathrm{Tg})$ for the second section and sodium iodide transporter (NIS) for 
the third one. The deparaffinized slides were incubated overnight at $4{ }^{\circ} \mathrm{C}$ with the primary antibody $\mathrm{Tg}$ (polyclonal antibody, Dako, Glostrup, Denmark) 1:3000 dilution. The binding of antibody was detected by a second antibody conjugated to peroxidase-labeled polymer (EnVision detection, DAKO) and peroxidase activity was revealed with 3-amino9-ethylcarbazole (DAKO) as chromogen, yielding a red product. The third sections were incubated with NIS antibody (polyclonal antibody, gift from Dr N Carrasco) 1:300 000 dilution overnight at $4{ }^{\circ} \mathrm{C}$. After the slides were incubated with biotinylated horse anti-rabbit secondary antibody (Jackson, West Grove, PA, USA), avidin-biotinylated enzyme complex (Dako) was added to bind the biotinylated secondary antibody. The immunoreactivity was visualized using $3,3^{\prime}$-diaminobenzidine, yielding a dark brown product. Sections were dehydrated and mounted in $p$-xylene-bis[ $N$-pyridinium bromide] (DPX) (BDH, Poole, UK) after counterstaining.

\section{Results}

Animals treated with $\mathrm{T}_{4}$ and $\mathrm{T}_{4}+$ acrylamide had to be killed after 6 months as they became obviously ill, and some died.

The weight of all animals increased slightly with time, reaching a plateau after 4 months. The weight of both the $\mathrm{T}_{4}-$ and $\mathrm{T}_{4}+$ acrylamide-treated mice increased faster and reached a plateau after 2 months (Fig. 1A). At the plateau, there was no significant difference in the weight of mice of the different experimental groups except in $\mathrm{T}_{4}+$ acrylamide group where the weight is slightly lower. This difference can be explained by the fact that these mice were in bad health.

The control and acrylamide-treated animals drank around $5 \mathrm{ml}$ water per day $(5 \mathrm{ml} \pm 1$ and $5.8 \mathrm{ml} \pm 1.3$ respectively; Fig. 1B). The MMI-treated animals drank slightly less, whether treated with acrylamide or not (around $4 \mathrm{ml} /$ day; $4 \cdot 4 \mathrm{ml} \pm 1 \cdot 1$ and $4.1 \mathrm{ml} \pm 1.3$ respectively). On the other hand, the $T_{4^{-}}$ treated animals drank much more (between 10 and $16 \mathrm{ml}$ per day; $12.1 \mathrm{ml} \pm 2 \cdot 6$ ) and this effect was further increased in $\mathrm{T}_{4} \pm$ acrylamide animals $(15-25 \mathrm{ml} /$ day $)(19 \cdot 1 \mathrm{ml} \pm 5 \cdot 7)$.

The acrylamide intakes achieved were $2.88 \pm 0.93 \mathrm{mg} / \mathrm{kg}$ per day for the controls, $2 \cdot 54 \pm 0 \cdot 72$ for the MMI-treated animals, and $4.41 \pm 1.02$ for the $T_{4}$-treated animals. After the increase of acrylamide concentration in drinking water during the last 2 months, the estimated intake of acrylamide was $13 \cdot 82 \pm 2 \cdot 38 \mathrm{mg} / \mathrm{kg}$ per day for the control and $13 \cdot 57 \pm$ 1.82 for the MMI-treated animals. These doses are at the high range of those causing mammary tumors in rats (Johnson et al. 1986, Friedman et al. 1995).

$\mathrm{T}_{4}$ intake was $0 \cdot 12 \pm 0 \cdot 02 \mathrm{mg} / \mathrm{kg}$ per day for the controls and $0.22 \pm 0.05$ for the acrylamide-treated mice. MMI intake was $22 \cdot 4 \pm 5 \cdot 4 \mathrm{mg} / \mathrm{kg}$ per day for the control and $20 \cdot 0 \pm 5 \cdot 87$ for the acrylamide-treated animals.

Serum thyroid hormones values at 2 months reflected the effect of thyroid status resulting from the treatments: increased $\mathrm{FT}_{3}$ and $\mathrm{FT}_{4}$ for $\mathrm{T}_{4}$-treated mice and decreased $\mathrm{FT}_{3}$ and $\mathrm{FT}_{4}$ (non-significant) and increased serum TSH functional activity

\section{A Weight of mice treated 6 and 8 months}

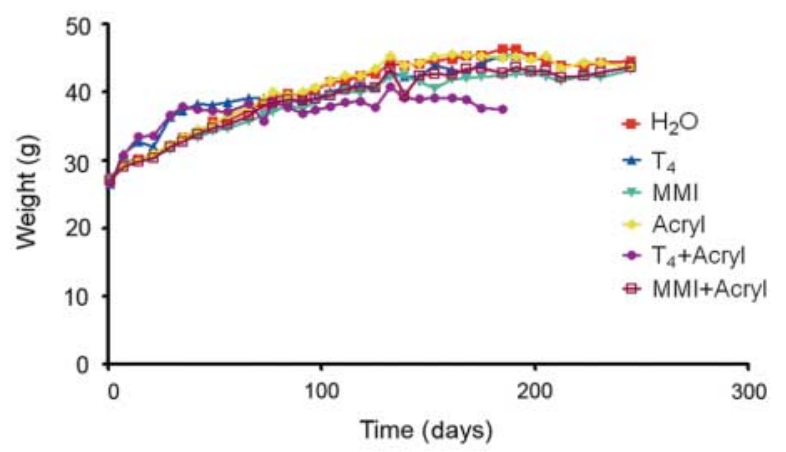

B Water intake of mice treated 6 and 8 months

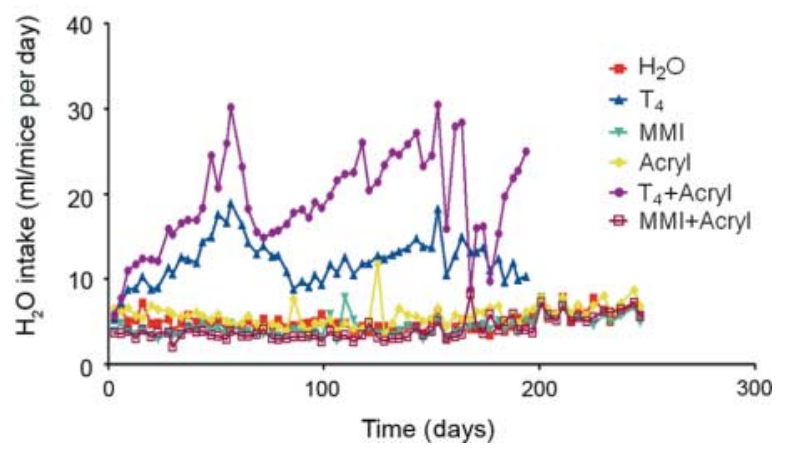

Figure 1 (A) Evolution of body weight expressed in grams of mice treated 6 and 8 months with $\mathrm{H}_{2} \mathrm{O}, \mathrm{T}_{4}$ (thyroxine), MMI (methimazole), Acryl (acrylamide), $\mathrm{T}_{4}$ with acrylamide, and $\mathrm{MMI}$ with acrylamide. The values presented are the means obtained by dividing the total weight of the mice in a group (two or three cages) by the number of mice in that group. (B) Water intake of mice treated 6 and 8 months with $\mathrm{H}_{2} \mathrm{O}, \mathrm{T}_{4}$ (thyroxine), MMI (methimazole), Acryl (acrylamide), $\mathrm{T}_{4}$ with acrylamide, and MMI with acrylamide expressed in milliliter per mouse per day. The values plotted are the means obtained by dividing the water consumption of a whole group (two or three cages) by the number of mice in that group.

(not significant) for the MMI-treated mice (data not shown). As expected, for the $\mathrm{T}_{4}$-treated mice, serum values of $\mathrm{FT}_{3}$ and $\mathrm{FT}_{4}$ in long-term treatment were markedly and significantly increased with or without acrylamide (Table 1). Moreover, for the mice treated with $\mathrm{T}_{4}+$ acrylamide, the values are twice as much as the $\mathrm{T}_{4}$-treated mice (Table 1 ). This is most probably due to the fact that the mice treated with $\mathrm{T}_{4}+$ acrylamide drank more than the mice treated with $\mathrm{T}_{4}$ alone (see Fig. 1B).

Serum TSH was measured by an in vitro bioassay. No significant difference in cAMP response to serum TSH was observed between the mice treated with and without acrylamide (Table 1). Higher, but non-significant, increased cAMP response was seen in the MMI-treated group with and without acrylamide. In the three mice with a much larger thyroid (47, 69, and 130) (Fig. 2) and those that showed epithelium hyperplasia with focal papillary projection $(47,69,130,142)$ (see Fig. $3 \mathrm{H}$ ), the cAMP response to serum TSH was much higher than the 
Table 1 Serum values of free tri-iodothyronine $\left(\mathrm{FT}_{3}\right)$, free thyroxine $\left(\mathrm{FT}_{4}\right)$, and thyrotrophin (TSH) estimation by bioassay in the long-term study

\begin{tabular}{|c|c|c|c|c|c|c|c|}
\hline & & & -Acrylamid & & & +Acrylamid & \\
\hline & Treatment & $\mathrm{FT}_{3}(\mathrm{pg} / \mathrm{ml})$ & $\mathrm{FT}_{4}(\mathrm{ng} / \mathrm{dl})$ & cAMP (pmoles) & $\mathrm{FT}_{3}(\mathrm{pg} / \mathrm{ml})$ & $\mathrm{FT}_{4}(\mathrm{ng} / \mathrm{dl})$ & cAMP (pmoles) \\
\hline Period & & & & & & & \\
\hline 6 months & $\mathrm{H}_{2} \mathrm{O}$ & $3 \cdot 78 \pm 0 \cdot 11$ & $3 \cdot 07 \pm 0 \cdot 51$ & $1 \cdot 78 \pm 0 \cdot 41$ & & & \\
\hline & $\mathrm{T}_{4}$ & $6 \cdot 05^{*} \pm 0 \cdot 58$ & $6.96^{*} \pm 0.53$ & $1 \cdot 01 \pm 0 \cdot 07$ & $15 \cdot 23^{*} \pm 3 \cdot 56$ & $14 \cdot 15^{*} \pm 2 \cdot 91$ & $1 \cdot 14 \pm 0 \cdot 03$ \\
\hline 8 months & $\mathrm{H}_{2} \mathrm{O}$ & $2 \cdot 93 \pm 0.08$ & $2 \cdot 17 \pm 0 \cdot 17$ & $2 \cdot 25 \pm 0.37$ & $3 \cdot 03 \pm 0 \cdot 14$ & $1 \cdot 89 \pm 0 \cdot 17$ & $2 \cdot 1 \pm 0 \cdot 33$ \\
\hline & MMI & $3 \cdot 28 \pm 0 \cdot 11$ & $1.43^{*} \pm 0.06$ & $4 \cdot 75 \pm 1 \cdot 94$ & $3 \cdot 05 \pm 0 \cdot 08$ & $1 \cdot 24 * \pm 0 \cdot 05$ & $3 \cdot 37 \pm 0 \cdot 57$ \\
\hline
\end{tabular}

Mean \pm S.E.M. $* P \leq 0 \cdot 001$.

mean of their group $(25 \times, 10 \times, 3 \cdot 5 \times, 4 \cdot 3 \times$ respectively). These mice belong to the MMI alone or MMI+ acrylamide groups. TSH levels were lower in the $\mathrm{T}_{4}$-treated mice but the effect was not significant.

For the long-term study, 2 out of 25 mice from the $\mathrm{T}_{4}$ group and 4 out of 25 mice from the $\mathrm{T}_{4}+$ acrylamide group died after 50 days of treatment. The mortality increased with time. After 6 months, 5 out of 25 mice from the $\mathrm{T}_{4}$ group and 10 out of 25 mice from the $\mathrm{T}_{4}+$ acrylamide group were dead. In the other four groups, during the 8-month treatment mortality was lower: 1 out of 20 from the control group, 2 out of 20 from the acrylamide group, 1 out of 30 from the MMI group, and 1 out of 30 mice from the MMI + acrylamide group.

The $\mathrm{T}_{4}$-treated animals with or without acrylamide progressively developed signs of hyperthyroidism i.e., loss of hair by plate, apathy, and in some cases death. Thyroid weights

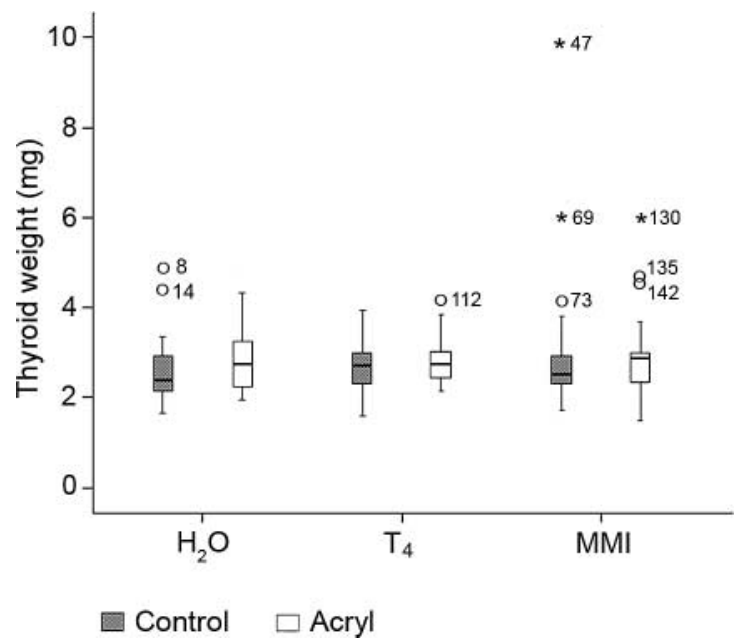

Figure 2 Box plot of thyroid weights expressed in milligrams after the long-term treatment with $\mathrm{H}_{2} \mathrm{O}, \mathrm{T}_{4}$ (thyroxine), $\mathrm{MMI}$ (methimazole), Acryl (acrylamide), $\mathrm{T}_{4}$ with acrylamide, and $\mathrm{MMI}$ with acrylamide. The central line, in a box plot, is the median, the boxes represent the interquartile range, and the whiskers represent the range of values that are not outliers. ' $O$ ' marks cases that are more than 1.5 box lengths from the 75 th percentile and ${ }^{\prime * \prime}$ marks cases that are three box lengths from the 75th percentile. Thyroid weight of mice: $8(4.9 \mathrm{mg}), 14(4.4 \mathrm{mg}), 47(9.9 \mathrm{mg}), 69(6.0 \mathrm{mg}), 73$ (4.2 mg), 112 (4.2 mg), 130 (6.0 mg), 135 (4.7 mg), 142 (4.6 mg). did not vary significantly between the various groups in the long-term study (Fig. 2). Some hyperplastic thyroids were found in the MMI-treated mice (3/58) (see above).

In the acrylamide group, 8 out of 18 mice showed weakness of the limbs, especially hind limbs. This is a classical response to high doses of acrylamide (Fullerton \& Barnes 1966). In four out of these eight mice, the weakness of the limbs was serious and in the other four mice it was present but less disabling. Mice were put on the lid wires of the cage, and if the mouse could hold the wires and walk on them, we considered that the mouse was normal; if the mouse could hold the wires quite weakly but could not walk on the wires, it was scored as medium weak; and if the mouse could not hold the wires at all, the four limbs just falling through the wires, it was scored serious. In two out of the four mice with very weak hind limbs, the urinary bladder was thrice enlarged and the thickness of the bladder wall was around thrice thinner than normal. In the acrylamide $+\mathrm{T}_{4}$ group, 2 out of 15 mice showed larger and thinner urinary bladders too.

Ovarian cysts (3.5-7 mm diameter) were observed in 2 out of 29 mice treated with MMI alone and the same observation was made in 2 out of 29 mice of the MMI + acrylamide group. In this latter group, a mouse presented a white hard spot in the lung that appeared, at histology, to be a lung adenoma.

In the 2-month short-term study, there was no mortality, no hind limbs weakness, no large and thin urinary bladder, no ovary cyst, and no tumor.

For the pituitaries, no statistically significant difference was seen in the mean weight of the groups with versus without, acrylamide treatment. The adrenal weights of both $\mathrm{T}_{4}$ and $\mathrm{T}_{4}+$ acrylamide groups $\left(9.7 \mathrm{mg}\right.$ for $\mathrm{T}_{4}$ and $9 \cdot 4 \mathrm{mg}$ for $\mathrm{T}_{4}+$ acrylamide) were statistically significantly higher than that in the other four groups $\left(4.7 \mathrm{mg} / \mathrm{H}_{2} \mathrm{O} ; 5.0 \mathrm{mg} /\right.$ acrylamide; $4 \cdot 6 \mathrm{mg} / \mathrm{MMI} ; 5 \cdot 1 \mathrm{mg} / \mathrm{MMI}+$ acrylamide). The medulla area of these heavier adrenal glands was significantly larger than that in other groups. Adipocytes and amyloid degeneration were replacing the normal cells in these enlarged medulla area.

There were no significant changes in thyroid weights and sizes of acrylamide compared with non-acrylamide-treated mice, in the $\mathrm{H}_{2} \mathrm{O}, \mathrm{T}_{4}$, and MMI groups (Fig. 2). When the thyroids of $\mathrm{T}_{4}$-treated mice $\left(\mathrm{T}_{4}\right.$ and $\mathrm{T}_{4}+$ acrylamide) were observed under the microscope, two types of image were seen. Type 1: areas with 'regular follicles', round follicles formed by flattened epithelium 


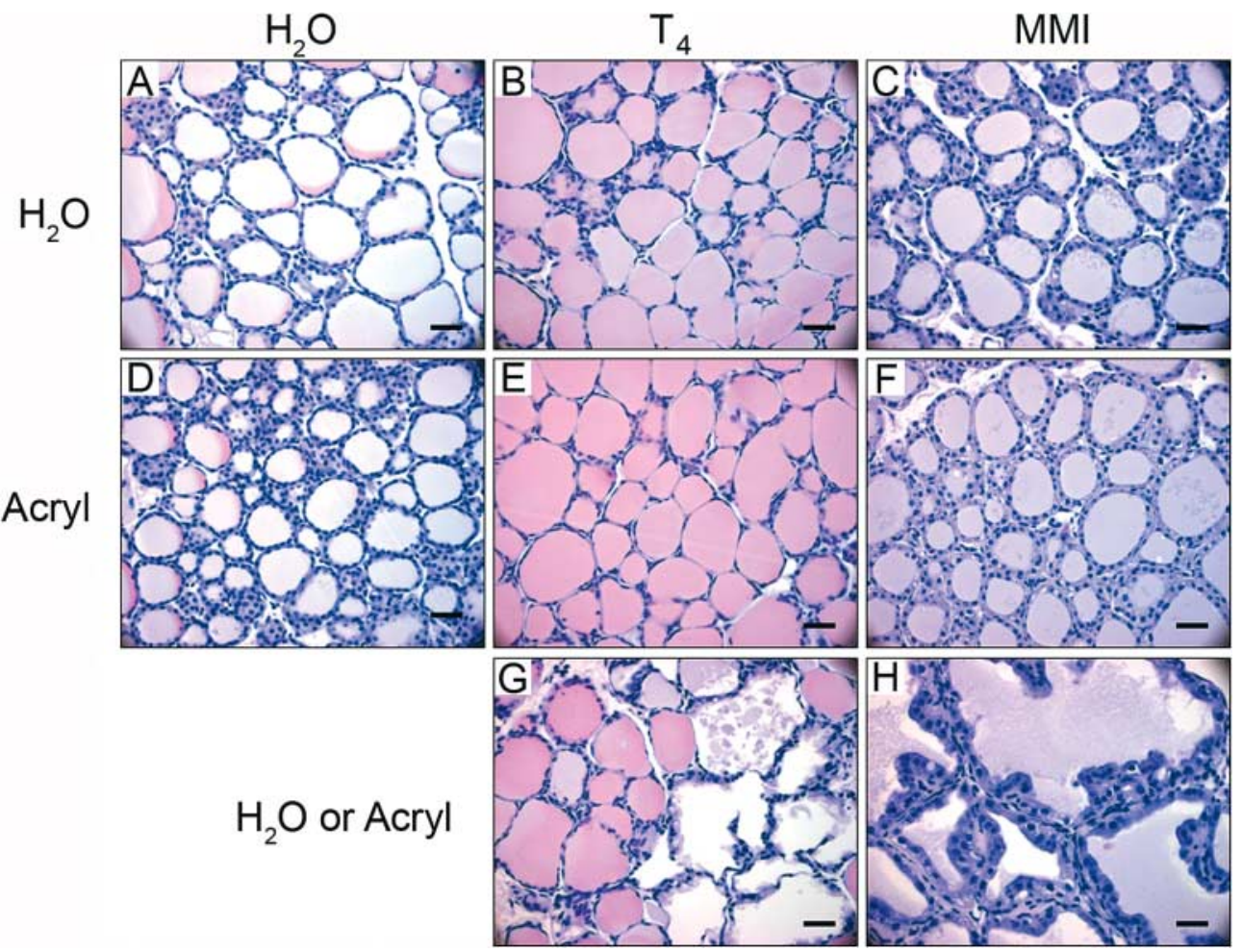

Figure 3 Hematoxiline-eosin staining of mice thyroids from: $(A), \mathrm{H}_{2} \mathrm{O}$ group; $(B)$, thyroxine $\left(\mathrm{T}_{4}\right)$ group; $(C)$, methimazole (MMI) group; (D), acrylamide group; (E), thyroxine + acrylamide (Acryl) group; (F), methimazole+ acrylamide; $(\mathrm{G})$, thyroxine group, mixed round cold follicles with disorganized irregular follicles; $(\mathrm{H})$, methimazole group, papillary hyperplasia (papillary projections), original magnification $40 \times$. Scale bar: $30 \mu \mathrm{m}$.

cells, eosinophilic stained colloid (Fig. 4B). There is no NIS expressed on the basolateral membrane of the thyrocytes (Fig. 4L) in the colloid of those follicles. Type 2: areas with less regular shaped follicles containing blue basophilic stained (H\&E) colloid (Fig. 4C), and a well-defined NIS labeling (Fig. 4M), or with large irregular follicles with apparent papillae often formed by tall hyperplastic epithelia. These cells were often lined with a cluster of microvillae, which stained positively for $\mathrm{Tg}$. The colloid was fragmented and in some cases disappeared completely. The two types of images were in some cases quite separated in two main zones of the tissue but in other cases, the 'type 2' images appeared in several areas among the 'type 1' areas.

$\mathrm{T}_{4}+$ acrylamide group could not be distinguished from $\mathrm{T}_{4}$ alone group (see Figs 3B, E, G and 4B, C, G, H, L, M).

In the MMI-treated groups, most of the thyroids showed a typical MMI stimulated view: follicles with taller epithelium cells (Fig. 3C) and almost all thyrocytes expressing well NIS (Fig. 4D, E, N and O). The thyroids from mice no 47, 69, 73 treated with MMI alone and the thyroids from mice no 130 and 142 treated with MMI+acrylamide showed epithelium hyperplasia with focal papillary projections. The NIS labeling was stronger in these five thyroids than in the others from the same group (Fig. $4 \mathrm{~N}$ and $\mathrm{O}$ ). The MMI+ acrylamide group could not be distinguished from the MMI alone group (see Fig. 3C, F and H; Fig. 4D, E, I, J, N and O).

\section{Discussion}

Long treatment of mice with acrylamide (6 and 8 months), at doses similar to those which caused thyroid tumorigenesis after 2 years in rats, failed to induce any thyroid tumor in mice with hyper- or hypo-stimulated thyroids.

In the absence of significant variations in the thyroid weight for variously treated mice, the efficacy of the treatments might be questioned. However, several experimental data demonstrate the effects of these treatments.

The mild hypothyroidism and consequent thyroid hyperstimulation induced by MMI are demonstrated by several findings: the lower consumption of water, the lower serum $\mathrm{FT}_{4}$ levels and the tendency for higher TSH levels after 8-month treatment, the histology with small follicles, and tall thyrocytes of the stimulated thyroids.

At 6 months, the hyperthyroidism and consequent thyroid quiescence induced by the $T_{4}$ treatment are demonstrated by several observations: the faster growth with an earlier weight plateau, a clinical syndrome with great loss of hair and apathy, early deaths, a greatly increased water consumption, the higher $\mathrm{FT}_{4}$ and $\mathrm{FT}_{3}$ serum levels, and a tendency for lower $\mathrm{TSH}$ levels, the higher weight of the adrenals, with the amyloid degeneration of the medulloadrenal, and the histology with large follicles and flat thyrocytes. 


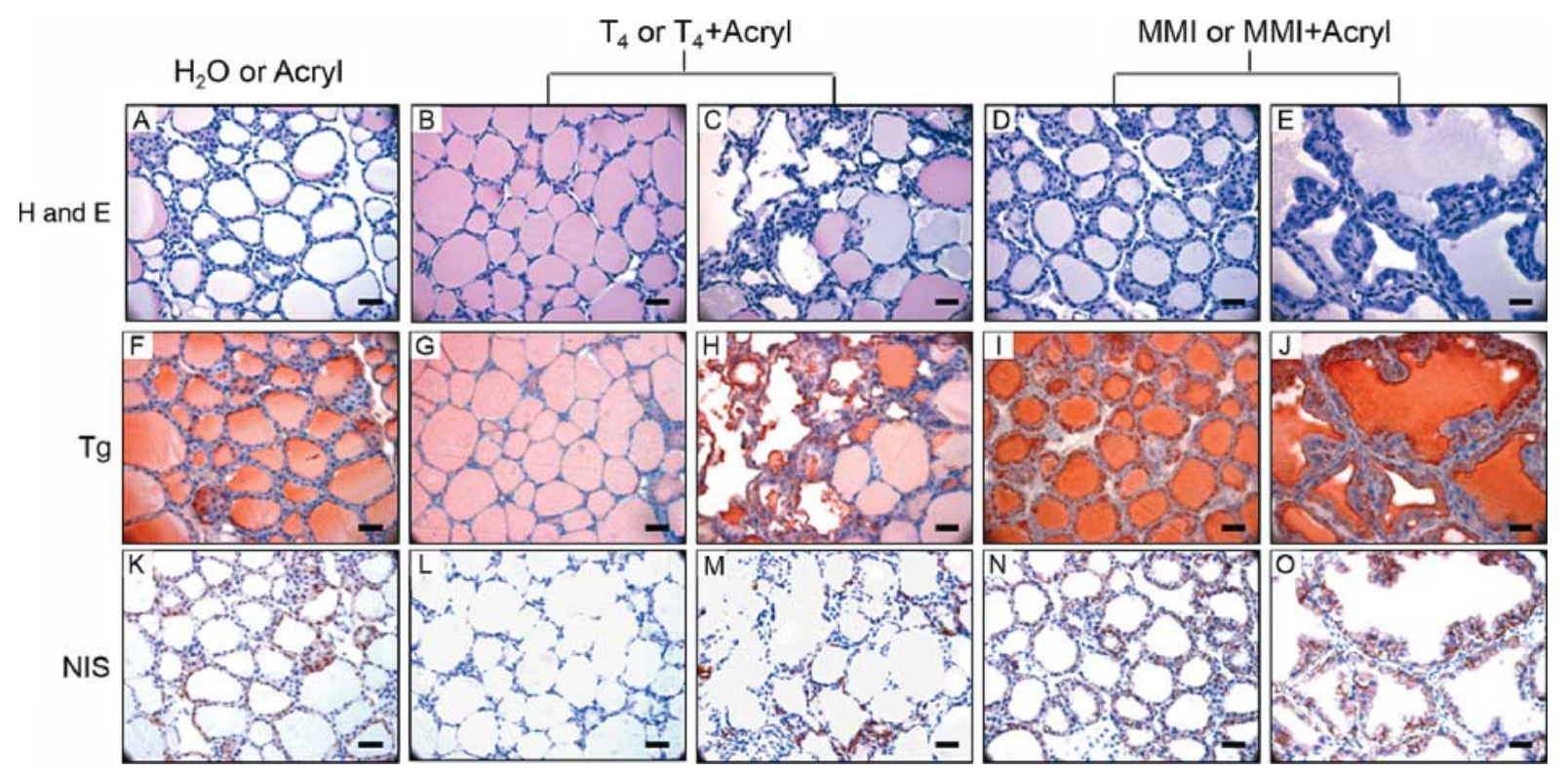

Figure 4 Hematoxiline-eosin staining of mice thyroids, thyroglobulin (Tg) and sodium-iodide symporter (NIS) staining: (A), (F), (K), for $\mathrm{H}_{2} \mathrm{O}$ and acrylamide groups; (B), (G), (L) (regular follicles region) and (C), (H), (M) (irregular follicles region) for thyroxine+acrylamide and thyroxine alone groups; (D), (I), (N) (majority of thyroids) and (E), (J), (O) (hyperplastic thyroids) for methimazole + acrylamide and methimazole alone groups. Original magnification $40 \times$. Scale bar: $30 \mu \mathrm{m}$.

Of course, as there was no tumor induction by acrylamide in any of the groups, the rationale of $\mathrm{T}_{4}$ and $\mathrm{MMI}$ treatments did not apply.

Polydypsia is a frequent consequence of Graves' disease hyperthyroidism in humans. On the other hand, a medulloadrenal degeneration has not been reported. Spontaneous amyloidosis has been observed in these mice strains (Chai 1978).

Acrylamide action on the mice is demonstrated by several observations:

1) the enhanced pharmacological effect of $T_{4}$ on water consumption and the consequent higher $\mathrm{FT}_{4}$ and $\mathrm{FT}_{3}$ levels in these mice,

2) the increased mortality of the $T_{4}$-treated mice,

3) the development of hind-leg paralysis in mice during higher level treatment with acrylamide, and

4) the development of urinary bladder distention, which has been attributed to the degeneration of the nerves involved in bladder voiding (Fullerton \& Barnes 1966).

The absence of significant effects of acrylamide on serum thyroid hormones and TSH levels is similar to the findings in rats (Khan et al. 1999). In this study as well, we did not see an effect of acrylamide on the histology of the gland similar to the results reported by Khan et al. (1999).

Lafferty et al. (2004) at similar doses of acrylamide observed increased levels of PCNA and an increased bromodeoxyuridine incorporation in the thyroid. They interpreted this as an increased proliferation rate but it could also reflect a DNA repair process. The finding of tumors after 2 years is compatible with both hypotheses. The absence of a growth effect on the thyroid in our acrylamide-treated mice as well as the in vitro induction of DNA damage by acrylamide in thyroid (Chico Galdo et al. 2006) would support the latter hypothesis.

Differences in the tumorigenic action of acrylamide in various species have been found for the induction of fibroadenomas of the breast. The hormonal mechanisms generating these tumors in F344 rat do not apply to humans (Shipp et al. 2006). There are even differences in the induction of tumor by acrylamide in the same species (Shipp et al. 2006).

On the other hand, a study carried out in mice treated with acrylamide showed an increase in lung and skin tumors, but this last type of tumor needed a 12-O-tetra decanoylphorbol-13-acetate promotion by local application (Bull et al. 1984).

Stricto sensu the absence of effects of acrylamide on thyroid tumorigenesis applies to the strain of mice used. The difference with some rat studies likely does not result from a different metabolism between the species as the main possible carcinogenic metabolite of acrylamide is glycidamide which is more produced in mice (Sumner et al. 1992). Of course, it is still possible that higher doses of acrylamide than those generally used or a longer treatment could still induce thyroid tumorigenesis in mice, but the total absence of any abnormality in the thyroid of our mice makes this improbable, and even if that was the case there would be no applicability of such findings to the much lower exposures in man. Nevertheless, our results cast some doubt about the generalization to humans of the thyroid carcinogenic effect of acrylamide obtained in one rodent species but not in another. It should be noted that studies of populations exposed to 
higher intakes of acrylamide, professionally or in the diet, did not reveal any increase in cancer incidence, although they suggest some neurotoxicity (Collins et al. 1989, Marsh et al. 1999, Mucci et al. 2003). Only epidemiological studies of thyroid nodules frequency by ultrasound in human with various levels of acrylamide exposure will definitely clarify this point for public health.

\section{Declaration of Interest}

The authors declare that there is no conflict of interest that would prejudice the impartiality of this scientific work.

\section{Funding}

This study was supported by a grant of SNF and by Fondation Rose et Jean Hoguet and Fonds David et Alice Van Buuren.

\section{Acknowledgements}

We thank Prof D Williams (Cambridge) who reexamined the histological part of this study and confirmed our diagnosis.

\section{References}

Blasiak J, Gloc E, Wozniak K \& Czechowska A 2004 Genotoxicity of acrylamide in human lymphocytes. Chemico-Biological Interactions 149 137-149.

Brooker G, Harper JF, Terasaki WL \& Moylan RD 1979 Radioimmunoassay of cyclic AMP and cyclic GMP. Advances in Cyclic Nucleotide Research 10 $1-33$.

Bull RJ, Robinson M, Laurie RD, Stoner GD, Greisiger E, Meier JR \& Stober J 1984 Carcinogenic effects of acrylamide in Sencar and A/J mice. Cancer Research 44 107-111.

Chai CK 1978 Spontaneous amyloidosis in LLC mice. American Journal of Pathology 90 381-397.

Chico Galdo V, Massart C, Jin L, Vanvooren V, Caillet-Fauquet P, Andry G, Lothaire P, Dequanter D, Friedman M \& Van Sande J 2006 Acrylamide, an in vivo thyroid carcinogenic agent, induces DNA damage in rat thyroid cell lines and primary cultures. Molecular and Cellular Endocrinology 257-258 6-14.

Collins JJ, Swaen GM, Marsh GM, Utidjian HM, Caporossi JC \& Lucas LJ 1989 Mortality patterns among workers exposed to acrylamide. Journal of Occupational Medicine 31 614-617.

Foth H, Degen GH \& Bolt HM 2005 New aspects in the classification of carcinogens. Arhiv za Higijenu Rada i Toksikologiju 56 167-175.
Friedman MA, Dulak LH \& Stedham MA 1995 A lifetime oncogenicity study in rats with acrylamide. Fundamental and Applied Toxicology 27 95-105.

Fullerton PM \& Barnes JM 1966 Peripheral neuropathy in rats produced by acrylamide. British Journal of Industrial Medicine 23 210-221.

Johnson KA, Gorzinski SJ, Bodner KM, Campbell RA, WolfCH, Friedman MA \& Mast RW 1986 Chronic toxicity and oncogenicity study on acrylamide incorporated in the drinking water of Fischer 344 rats. Toxicology and Applied Pharmacology 85 154-168.

Khan MA, Davis CA, Foley GL, Friedman MA \& Hansen LG 1999 Changes in thyroid gland morphology after acute acrylamide exposure. Toxicological Sciences 47 151-157.

Lafferty JS, Kamendulis LM, Kaster J, Jiang J \& Klaunig JE 2004 Subchronic acrylamide treatment induces a tissue-specific increase in DNA synthesis in the rat. Toxicology Letters 154 95-103.

Marsh GM, Lucas LJ, Youk AO \& Schall LC 1999 Mortality patterns among workers exposed to acrylamide: 1994 follow up. Occupational and Environmental Medicine 56 181-190.

Mucci LA, Dickman PW, Steineck G, Adami HO \& Augustsson K 2003 Dietary acrylamide and cancer of the large bowel, kidney, and bladder: absence of an association in a population-based study in Sweden. British Journal of Cancer 88 84-89.

Perret J, Ludgate M, Libert F, Gerard C, Dumont JE, Vassart G \& Parmentier M 1990 Stable expression of the human TSH receptor in CHO cells and characterization of differentially expressing clones. Biochemical and Biophysical Research Communications 171 1044-1050.

Pohlenz J, Maqueem A, Cua K, Weiss RE, Van Sande J \& Refetoff S 1999 Improved radioimmunoassay for measurement of mouse thyrotropin in serum: strain differences in thyrotropin concentration and thyrotroph sensitivity to thyroid hormone. Thyroid 9 1265-1271.

Shipp A, Lawrence G, Gentry R, McDonald T, Bartow H, Bounds J, Macdonald N, Clewell H, Allen B \& Van Landingham C 2006 Acrylamide: review of toxicity data and dose-response analyses for cancer and noncancer effects. Critical Reviews in Toxicology 36 481-608.

Sumner SC, MacNeela JP \& Fennell TR 1992 Characterization and quantitation of urinary metabolites of [1,2,3-13C]acrylamide in rats and mice using 13C nuclear magnetic resonance spectroscopy. Chemical Research in Toxicology $\mathbf{5}$ 81-89.

Tanii H \& Hashimoto K 1983 Neurotoxicity of acrylamide and related compounds in rats. Effects on rotarod performance, morphology of nerves and neurotubulin. Archives of Toxicology 54 203-213.

Tyl RW, Marr MC, Myers CB, Ross WP \& Friedman MA 2000 Relationship between acrylamide reproductive and neurotoxicity in male rats. Reproductive Toxicology 14 147-157.

Received in final form 9 May 2008

Accepted 15 May 2008

Made available online as an Accepted Preprint 15 May 2008 